\title{
Cross-Sectoral Coordination in Peatland Management Policy
}

\author{
Zulkarnaini' $^{1)}$, Mimin Sundari Nasution' ${ }^{2)}$, Gevisioner ${ }^{3)}$ \\ 1,2). Program Study Public Administration, Faculty Social and Politic, University of Riau, Indonesia \\ 3). Regional Planning, Research and Development Agency of Riau Province, Pekanbaru \\ *Coresponding Author \\ Email : zulkarnainfisip@lecturer.unri.ac.id
}

\begin{abstract}
This paper analyzes the many problems caused by errors in peatland management in Riau Province. In the province which is the largest peat area on the island of Sumatra, there is a decline in the quality of peat swamp land caused by various interests, especially the exploitation of natural resources that considers the level of sustainability and sustainability. This study uses a policy analysis approach. The results of the study show that there is a lack of attention to the importance of peatlands in supporting sustainable development and that there is no institution that is given the responsibility for managing and protecting the existence of peatlands. Peatlands are heavily affected by various conflicts and overlapping policies. As a result, various forms of peatland management activities in Riau Province are still carried out by certain agencies with an inadequate level of understanding of conservation issues. In the case of clearing agricultural land or settlements on deep peatlands that do not pay attention to water and land conservation aspects, even though such areas must be protected.
\end{abstract}

Keywords: Government Policies, Law Enforcement, Management Strategies, Peatlands

\section{INTRODUCTION}

Peatlands are an ecological unit that should be managed based on the boundaries of their ecosystems even though the ecosystem boundaries cross administrative boundaries or the authority of certain agencies (Rivai, et al, 2006). Management practices with reference to ecosystem boundaries become more difficult if there is no coordinating and fully responsible agency (Clarke \& Rieley, 2010). In this regard, it is acknowledged that up to now there is no institution either at the central or regional level that has full responsibility and authority in implementing or coordinating peatland management activities.

Stakeholders on peatland actually consist of many parties, but mechanisms that can be applied for cross-sectoral coordination are not yet available adequately (Brown, 2020). The absence of special institutions and weak communication and coordination between agencies (cross-sectoral) in local governments or between local governments and the central government cause peatland management activities to become conflict-prone. Even in some places, especially in Riau Province, this weakness has threatened the sustainability of natural resources (Sari, et al, 2021).

In Riau Province, peatland management has not yet bound all stakeholders and all activity implementers. Peatland management does not pay attention to strong institutions including aspects of area control and accountability, organizational aspects, institutional capacity aspects, and financing aspects. Another problem that is no less important is the low level of community participation in the formulation of peatland management policies 
(Nugraheni \& Pangaribuan, 2008). This problem causes the implementation of various policies that are still contradictory, prone to conflict and difficult to implement.

The problem becomes more complicated by the existence of institutional weaknesses, weaknesses in the content of regulations/laws and policies themselves which trigger difficulties in implementing (enforcement) these laws and policies in peatland management (Rivai, et al, 2006). Another thing that is also very influential on the effectiveness of the implementation of law enforcement and policies is generally determined by the ability to understand and aware of the law of the wider community, including compliance with laws and policies themselves.

The low level of community participation in developing peatland management plans also makes the activities that will be carried out or programmed become one-sided and less sensitive to local culture. Often the plans and implementation of peatland management activities are not adapted to local conditions. Appreciation and use of traditional wisdom that should be the basis for peatland management at the local level is still relatively low or even neglected.

\section{RESEARCH METHODS}

This study uses a policy analysis approach. Policy analysis is a technique used in public administration to examine and evaluate the policies of a public organization in achieving goals. Policy analysis is the process or activity of synthesizing information, including research results, to produce recommendations for public policy design options. Because public policy is a government decision or action that influences or leads to individual actions in community groups, it is necessary to have a public policy analysis to find out in detail the impact / results / consequences resulting from a policy issued by the government in people's lives, whether the policy has been implemented or not. right or not in implementation

\section{RESULTS AND DISCUSSION}

These peatlands have real importance for socio-economic development and support the lives of local communities (Glenk \& Martin-Ortega, 2018). In addition, peatlands, if managed properly or maintained their natural nature will be able to provide various environmental services for humans and other living creatures on/around it. Among them are tackling the impacts of global climate change through its ability to absorb and store large amounts of carbon, regulating water systems (hydrology), habitats for unique biodiversity, food supplies for humans (especially freshwater fish and other natural products), wood, forest products. nonwood (eg rattan and honey) and so on. However, this role is often neglected due to incompatibilities (even conflicts) between existing policies.

The condition of peatlands in Riau Province is currently experiencing increasingly severe pressure, especially by intensive and extensive forest exploitation and land clearing activities, to meet industrial needs (eg HTI) as well as to increase food production (eg oil palm plantations) (Nasrul \& Nedi, 2018). These activities directly or indirectly lead to the degradation of the peatland ecosystem. This degradation is caused by land preparation that still uses a fire system, construction of ditches/channels for drainage facilities, transportation of forest and non-forest products which causes peat water to drain so that the peat becomes dry and easy to burn or undergo subsidence. Over the past 10 years, the conversion of peatlands to oil palm and pulpwood plantations, unsustainable logging and large-scale agriculture is estimated to have damaged around 6 million ha of peatlands. 
This condition is certainly more worrying with the discourse to make peat as a source of energy. This discourse really needs attention and in-depth study. Utilization of peat as a mining material/energy source means it will reduce its volume (Humpenöder, et al, 2020). This will certainly reduce the value/benefit of peat related to physical properties that are directly or indirectly related to volume, for example the ability to hold water, and that means a reduced function of peat as flood control.

Forest fires are one of the main causes of tropical forest destruction in Indonesia. In $1997 / 98$ it was recorded that around 2,124,000 ha of peat swamp forest in Indonesia were burned (Tacconi, 2003). In fact, there are many cases of re-burning of the same location several times (multiple fires). Most of the fires that occur in peat forests are classified as severe considering the characteristics of the peat itself which is composed of decayed organic matter litter with vegetation on it which has the potential as fuel.

The accumulation of weathered organic matter that composes the peat layer has the potential to cause a ground fire (Ardjakusumah, et al, 2005). A condition where the fire is below the peat surface, while the flat surface makes it easier for fire to spread from one tree to another or between tree canopies when a fire occurs above the surface. As a result, fires often occur on peatlands simultaneously below and above the surface so that the impact on the environment and loss of biodiversity becomes even worse. After the fire, the vegetation above the peat surface disappears and the layer of peat soil decreases and forms a basin so that during the rainy season it becomes waterlogged like a lake. This puddle is a medium for spreading seeds because of the vegetation that appears after the fire.

Forest and peatland fires occur almost every year in Riau Province, especially in the dry season. These fires usually occur in community-owned areas, plantation areas, HPH areas, HTI areas, even in protected areas. Some fires are caused by land preparation activities by the community using fire (Suriadikarta, 2009). The technique of land preparation through burning is still considered the cheapest and most practical way, so that some plantation companies and HTI with more economical reasons are still doing it even though it is legally prohibited.

Based on the facts, almost all forest fires are caused by human activities (intentionally or not) and there is no evidence of fires occurring naturally. It is not realized that the impact caused by peatland fires is not only difficult to extinguish, because the fire is below the surface and the location is far away and the limitations of tools and technology will also cause air pollution (Whitfield, et al, 2011).

So far the management of peatlands by the community has been carried out without adequate technical guidance from the relevant agencies. The fire technique applied by the community in land clearing and excessive drainage tends to cause the destruction of peatlands. Technical barriers (including low fertility, subsidence due to drainage etc.) are often not recognized from the start. Furthermore, the failures resulting from this activity caused the farmers to leave these lands in a damaged state.

If it is observed, there are various similarities in the problems faced by Regency/City/Provincial Governments that own peatlands, related to peatland management. Problems that often arise include fire, drainage, inadequate management practices, livelihood sustainability, sustainability issues, and so on. In addition to the similarity of problems, there are also similarities in terms of needs in the fields of awareness/education/information exchange, capacity building/training, fire prevention and control, wise use, peatland rehabilitation, peatland inventory, research, pilot projects..

Each party related to peatland management is expected to have the same perspective on peatland (Clarke \& Rieley, 2010). With this same view, it is hoped that it will reduce the possibility of the emergence of conflicting management strategies and activities. Peatlands 
naturally follow a certain physiographical form and do not recognize administrative boundaries.

In its management, peatlands must be viewed as a unified whole ecosystem with the peat dome as the center. Peat is a growing medium, it has certain physical and chemical properties which together with other environmental factors have resulted in a unique ecosystem with unique biodiversity (Urák, et al, 2017). Any treatment of peat outside of treatment as a medium for growing will give the possibility of negative environmental influences/impacts that are greater than the benefits obtained.

In the future, of course, it is important to create a basic framework that is general in nature in tackling various (similar) problems in peatlands to stakeholders. In this way, actors from different locations can share experiences with each other in implementing action programs for sustainable peatland management. In this way, unnecessary duplication of efforts/activities can be avoided and energy and money savings can be made.

\section{CONCLUSION}

Various forms of peatland management activities in Riau Province are still carried out by certain agencies with an inadequate level of understanding of conservation issues. For example, in the case of clearing agricultural land or settlements on deep peatlands that do not pay attention to water and land conservation aspects, even though such areas must be protected. From this condition, it can be seen that there is a lack of coordination between agencies engaged in the peatland conservation sector. Likewise, the lack of supervision carried out by the government on forest management concession holders who have expired, and management land is not returned, so that the status of the land becomes unclear who is responsible for managing these lands. This condition resulted in the open land being exploited by local communities to take forest products. As a result, exploitation of forests and peatlands is proven unsustainable, forests that have been cut down are allowed to be damaged and turn into unproductive swamps.

\section{REFERENCES}

Ardjakusumah S., Nur'ani, E. Sumantri. (2005) Teknik Penyiapan Pada Lahan Gambut Bongkor untuk Tanaman Holtikultura. Pusat Penelitian Tanah dan Agroklimat - Bogor

Brown, I. (2020). Challenges in delivering climate change policy through land use targets for afforestation and peatland restoration. Environmental Science \& Policy, 107, 36-45.

Clarke, D., \& Rieley, J. (Eds.). (2010). Strategy for responsible peatland management. Finland: International Peat Society.

Glenk, K., \& Martin-Ortega, J. (2018). The economics of peatland restoration. Journal of Environmental Economics and Policy, 7(4), 345-362.

Humpenöder, F., Karstens, K., Lotze-Campen, H., Leifeld, J., Menichetti, L., Barthelmes, A., \& Popp, A. (2020). Peatland protection and restoration are key for climate change mitigation. Environmental Research Letters, 15(10), 104093. 
Nasrul, B., Hamzah, A., \& Nedi, S. (2018) Model Pengelolaan Perkebunan Kelapa Sawit Berkelanjutan Pada Lahan Gambut di Provinsi Riau. Jurnal Agroteknologi Tropika, 1(1), 8-13.

Nugraheni, E., \& Pangaribuan, N. (2008). Pengelolaan lahan pertanian gambut secara berkelanjutan. Universitas Terbuka, Tangerang Selatan Universitas Pajajaran, 73-88.

Rivai, S., Hilman, M., Mallolongan, A., \& Mawardi, A. (2006). Strategi dan Rencana Tindak Nasional Pengelolaan Lahan Gambut Berkelanjutan. Kelompok Kerja Pengelolaan Lahan Gambut Nasional. Departemen Dalam Negeri Jakarta.

Sari, D. A., Margules, C., Lim, H. S., Widyatmaka, F., Sayer, J., Dale, A., \& Macgregor, C. (2021). Evaluating policy coherence: A case study of peatland forests on the Kampar Peninsula landscape, Indonesia. Land Use Policy, 105, 105396.

Suriadikarta, D. A. (2009). Pembelajaran dari kegagalan penanganan kawasan PLG sejuta hektar menuju pengelolaan lahan gambut berkelanjutan. Pengembangan Inovasi Pertanian, 2(4), 229-242.

Tacconi, L., Boscolo, M., \& Brack, D. (2003). National and international policies to control illegal forest activities. Royal Institute of International Affairs.

Urák, I., Hartel, T., Gallé, R., \& Balog, A. (2017). Worldwide peatland degradations and the related carbon dioxide emissions: the importance of policy regulations. Environmental Science \& Policy, 69, 57-64.

Whitfield, S., Reed, M., Thomson, K., Christie, M., Stringer, L. C., Quinn, C. H., ... \& Hubacek, K. (2011). Managing peatland ecosystem services: current UK policy and future challenges in a changing world. Scottish Geographical Journal, 127(3), 209-230 